\title{
Covid-19: balancing personal risk and professional duty
}

\author{
Denis W Harkin consultant surgeon and clinical lead
}

Belfast Health and Social Care Trust, Royal Victoria Hospital, Belfast BT12 6BA, UK

The covid-19 pandemic is a global health and societal emergency ${ }^{1-3}$; doctors and healthcare workers will stand together on the front line making life and death decisions at personal risk. Together we shall endure this challenge, relying on our medical professionalism.

The ancient oath of Hippocrates ${ }^{4}$ bound physicians to act for patients' benefit and to do no harm. Today the principles of medical professionalism - the primacy of patient welfare, patient autonomy, and social justice ${ }^{5}$ - underpin public trust ${ }^{6}$ and our professional codes. ${ }^{7}$ Doctors must act in patients' best interests, but covid-19 pneumonia death rates are highest in elderly people with comorbid disease, and life support for some will be futile. ${ }^{8}$ Transmission in hospital has led to hundreds of healthcare workers dying worldwide. ${ }^{89}$ But doctors, nurses, and healthcare workers continue to selflessly face risk to help patients and colleagues. During a pandemic, some best interests of individuals are secondary to those of society.

In partnership, doctors empower patients to make informed choices. But in law, patient autonomy does not entitle everyone to any requested treatment, regardless of advisability or scarcity of resource. ${ }^{10}$ We are under no obligation to offer treatment we consider futile, but to withhold or withdraw life support because of scarcity creates a dichotomy for the doctor between patient advocate and public servant. In a pandemic, some choices are restricted. Social justice demands that we consider the needs of all while treating an individual. In epicentres, healthcare systems overwhelmed by demand for ventilators have not had enough, and necessity has directed care to likely survivors. ${ }^{10}$ These grave decisions should be taken openly, in partnership, while recognising that uncertainty exists. Treatment delays will bring collateral harm and need later redress.
Doctors will endure this epidemic with medical professionalism, balancing personal risk and professional duty, but reciprocally, society must ensure that staff are supported, throughout the pandemic and beyond.

\section{Competing interests: None declared.}

Full response at: https://www.bmj.com/content/368/bmj.m1199/rr-4.

1 World Health Organization. WHO director-general's opening remarks at the media briefing on covid-19.11 March 2020. https://www.who.int/dg/speeches/detail/who-director-generals-opening-remarks-at-the-media-briefing-on-covid-19---11-march-2020

2 Guan WJ, Ni ZY, Hu Y, etal. China Medical Treatment Expert Group for Covid-19. Clinical characteristics of coronavirus disease 2019 in China. N Engl J Med 2020 10.1056/NEJMoa2002032. 32109013

3 Godlee F. Covid-19: weathering the storm. Editor's choice. BMJ 2020;368:m119910.1136/bmj.m1199

4 Adams F. The Oath of Hippocrates. In: The Genuine Works of Hippocrates. Volume 2. London, 1849.

5 ABIM Foundation. American Board of Internal MedicineACP-ASIM Foundation. American College of Physicians-American Society of Internal MedicineEuropean Federation of Internal Medicine. Medical professionalism in the new millennium: a physician charter. Ann Intern Med 2002;136:243-6. 10.7326/0003-4819-136-3-200202050-00012 11827500 6 Working Party of the Royal College of Physicians. Doctors in society. Medical professionalism in a changing world. Clin Med (Lond) 2005;5(Suppl 1):S5-40.16408403 General Medical Council. Good medical practice. 2013. https://www.gmc-uk.org/ethicalguidance/ethical-guidance-for-doctors/good-medical-practice

8 Yang S, Cao P, Du P, etal . Early estimation of the case fatality rate of COVID-19 in mainland China: a data-driven analysis. Ann Transl Med 2020;8:128. 10.21037/atm.2020.02.66 32175421

9 Gan N, Thomas N, Culver D. Over 1,700 frontline medics infected with coronavirus in China, presenting new crisis for the government. 2020 CNN 2020 Feb 14 https://edition. cnn.com/2020/02/13/asia/coronavirus-health-care-workers-infected-intl-hnk/index.html

10 Gedge E, Giacomini M, Cook D. Withholding and withdrawing life support in critical care settings: ethical issues concerning consent. J Med Ethics 2007;33:215-8. 10.1136/jme.2006.017038 17400619

Published by the BMJ Publishing Group Limited. For permission to use (where not already granted under a licence) please go to http://group.bmj.com/group/rights-licensing/ permissions 